\title{
Penyuluhan Pengolahan Perikanan pada Poklahsar di Kecamatan Darma, Kabupaten Kuningan, Jawa Barat
}

\author{
[Fishery Processing Extension at Poklahsar in Darma District, Kuningan \\ Regency, West Java]
}

\section{Ria Irama Kristiani Sigalingging, OD Soebhakti Hasan, Tuti Susilawati}

Program Studi Penyuluhan Perikanan, Politeknik Ahli Usaha Perikanan Jl. Cikaret No. 2 Bogor Selatan Kota Bogor

\begin{abstract}
Abstrak
Kecamatan Darma terletak di Kabupaten Kuningan, mempunya sumber daya alam berupa Waduk yang digunakan untuk perikanan budidaya. Kelompok pengolah dan pemasar (poklahsar) di sekitar waduk belum memanfaatkan ikan untuk membuat olahan karena karakteristik ikan yang kurang disukai. Tujuan dari penelitian ini adalah mempelajari perubahan pengetahuan, sikap dan keterampilan pada pelaku usaha perikanan di sekitar Kecamatan Darma, khususnya pelaku usaha perikanan di sekitar Waduk Darma, terhadap sanitasi dan higiene produksi olahan ikan dan diversifikasi olahan ikan. Penyuluhan dilakukan menggunakan metode demonstrasi cara, diskusi dan praktik. Sasaran penyuluhan adalah 22 orang pelaku usaha pengolahan ikan yang tergabung dalam tiga poklahsar. Materi penyuluhan adalah penerapan prinsip sanitasi dan higiene pada produksi olahan ikan dan diversifikasi olahan ikan. Hasil evaluasi penyuluhan menunjukkan bahwa terjadi peningkatan pada aspek pengetahuan mengenai aneka macam olahan ikan. Aspek sikap terhadap diversifikasi olahan ikan. Pada saat sebelum penyuluhan, sasaran cukup setuju terhadap diversifikasi olahan ikan, kemudian menjadi sangat setuju terhadap diversifikasi olahan ikan. Namun pada tingkatan adopsi inovasi, belum ada sasaran yang mau untuk menerapkan prinsip sanitasi higiene. Pendampingan terhadap pelaku usaha perlu dilakukan agar tercapai penerapan prinsip tersebut.
\end{abstract}

Kata kunci: adopsi inovasi; diversifikasi; ikan nila; penyuluhan

\section{Abstract}

Darma Subdistrict is located in Kuningan Regency, has natural resources in the form of a reservoir which is used for aquaculture. Processors and marketers (poklahsar) around the reservoir have not used fish to make preparations because of the fish's characteristics that are not preferred. The purpose of this research is to study changes in knowledge, attitudes and skills of fishery business actors around Darma Subdistrict, especially fishery business actors around Darma Reservoir, on sanitation and hygiene in processed fish production and diversification of processed fish. Extension was carried out using demonstration methods, discussions and practices. The target of the extension is 22 fish processing business actors who are members of the three Poklahsar. The extension material is the application of sanitation and hygiene principles in processed fish production and diversification of processed fish. The results of the extension evaluation showed that there was an increase in the aspect of knowledge regarding various kinds of processed fish. Attitude aspect towards fish processed diversification. Before the extension program, the target group was quite agreeable to the diversification of processed fish, then they were very much in agreement with the diversification of processed fish. However, at the level of innovation adoption, there are no targets who want to apply the principles of hygiene sanitation. It is necessary to provide assistance to business actors in order to achieve the application of these principles.

Key words: innovation adoption; diversification; tilapia; counseling 


\section{Penulis Korespondensi}

Ria Irama Kristiani Sigalingging | riairama67@gmail.com

\section{PENDAHULUAN}

Kecamatan Darma merupakan salah satu wilayah bagian dari Kabupaten Kuningan Provinsi Jawa Barat dengan luas wilayah sebesar $50,23 \mathrm{~km}^{2}$. Kecamatan Darma terdiri dari 19 desa. Wilayah kecamatan berbatasan dengan Kecamatan Cigugur dan Gunung Ciremai di sebelah utara; Kabupaten Majalengka di sebelah barat; Kecamatan Nusaherang, Kadugede, dan Hantara di sebelah timur; dan Kabupaten Ciamis di sebelah selatan. Sebagian besar lahan di Kecamatan Darma dimanfaatkan pada bidang pertanian yaitu sebesar $2.747 \mathrm{Ha}$ untuk palawija, 1.408 Ha untuk pertanian, dan 392,77 Ha untuk perkebunan dengan lahan irigasi yang lebih kecil yaitu $620 \mathrm{Ha}$ (BPS Kabupaten Kuningan Jawa Barat 2018).

Kecamatan Darma memiliki waduk yaitu Waduk Darma. Waduk ini merupakan potensi alam yang menjadi salah satu sektor pengembangan kegiatan perikanan terbesar di Kabupaten Kuningan. Kegiatan perikanan utama yang dilaksanakan di waduk Darma adalah kegiatan budidaya ikan pada keramba jaring apung (KJA) dengan capaian produksi $3.459,1$ ton $(1.605,4$ ton ikan nila dan 1.593,5 ton ikan mas) pada tahun 2017.
Adapun produksi dari kegiatan perikanan tangkapnya sebesar 112,5 ton di tahun 2017 dengan komoditas dominan ikan mujair (BPS Kabupaten Kuningan Jawa Barat 2018).

Potensi perikanan di Waduk Darma belum tergarap dengan baik. Sekitar $50 \%$ pelaku perikanan pada kecamatan ini berada pada tingkat ekonomi menengah ke bawah. Sumber daya ikan dari Waduk Darma belum dimanfaatkan dengan maksimal. Ikan hasil budidaya belum menjadi bahan baku untuk produk olahan. Terdapat permasalahan yaitu rendahnya variasi produk olahan perikanan yaitu rata-rata 2 produk/pengolah yang disebabkan oleh $90 \%$ pelaku pengolah ikan kurang memahami diversifikasi produk olahan perikanan. Selain itu cara produksi olahan ikan juga belum sesuai dengan kaidah sanitasi higiene (Sigalingging 2019).

Penyuluhan merupakan suatu strategi dalam menyelesaikan permasalahan yang terjadi pada pelaku usaha perikanan untuk meningkatkan kesejahteraannya (Putri, Yuniarti, dan Dewi 2019). Tujuan penelitian adalah mempelajari perubahan pengetahuan, sikap dan keterampilan pada pelaku usaha perikanan di sekitar Kecamatan Darma, khususnya 
Tabel 1 Sasaran penyuluhan

\begin{tabular}{lll}
\hline No & Nama Responden & Asal Kelompok \\
\hline & Nung & Jaragarasa \\
2 & Ani Hanifah & Jaragarasa \\
3 & Mimin R & Jaragarasa \\
4 & Upi & Jaragarasa \\
5 & Irma & Jaragarasa \\
6 & Yadi & Jaragarasa \\
7 & Jumiati & Jaragarasa \\
8 & Deri Nurhidayat & Sagara Rasa \\
9 & Shafiatul Wardah & Sagara Rasa \\
10 & Tati Sumiati & Sagara Rasa \\
11 & Rodiah & Sagara Rasa \\
12 & Dede Sulaiman & Sagara Rasa \\
13 & Fatwa gilang R & Sagara Rasa \\
14 & Desy & Sagara Rasa \\
15 & Jaja S & Mina Sawargi \\
16 & Wahab & Mina Sawargi \\
17 & Yayan Muhyan & Mina Sawargi \\
18 & Hermana & Mina Sawargi \\
19 & Ahmad Hidayat & Mina Sawargi \\
20 & Ahmad Tatang S & Mina Sawargi \\
21 & Agus & Mina Sawargi \\
22 & Ade (Istri Hermana) & - \\
\hline & & \\
\hline
\end{tabular}

pelaku usaha perikanan di sekitar Waduk Darma, terhadap sanitasi dan higiene produksi olahan ikan dan diversifikasi olahan ikan.

\section{BAHAN DAN METODE}

Penelitian dilaksanakan pada tanggal 11 Maret sampai dengan 24 Mei 2019 yang bertempat di Kecamatan Darma Kabupaten Kuningan Provinsi Jawa Barat. Materi penyuluhan yang disampaikan adalah mengenai penerapan prinsip sanitasi higiene pada produksi olahan ikan dan diversifikasi olahan ikan. Sebelum penyuluhan, dilakukan sosialisasi terlebih dahulu. Sosialisasi penyuluhan merupakan proses persiapan pelaksanaan penyuluhan yang bertujuan untuk memberikan pemahaman dan penjelasan awal kepada sasaran maupun seluruh pihak/instansi yang terlibat pelaksanaan beberapa program penyuluhan. Freku- 
ensi penyuluhan masing-masing tema adalah empat pertemuan dan praktik. Metode penyuluhan adalah demonstrasi cara, diskusi dan praktik. Peralatan untuk penyuluhan antara lain; lembar persiapan penyuluhan (LPM), folder, video, softcopy file berbentuk powerpoint, dan model/benda nyata.

Sasaran penyuluhan adalah 22 rumah tangga produksi (RTP) dari tiga poklahsar di sekitar Waduk Darma Kecamatan Darma. Berikut adalah sasaran pada penelitian ini yang disajikan pada Tabel 1.

Penyuluhan mengenai diversifikasi olahan ikan meliputi cara pembuatan dendeng ikan, nugget ikan dan bakso ikan. Peralatan yang diperlukan antara lain kompor gas, baskom, pisau, talenan, blender, panci, saringan/ serokan, sendok makan, timbangan dan lainlain. Pembuatan dendeng ikan menggunakan metode (Harnisah, Riyadi, dan Jaya 2018). Tahapan pembuatan dendeng ikan nila yaitu memilih ikan nila yang segar, kemudian disiangi dan dibersihkan. Selanjutnya, ikan Nila dipotong kurang lebih $3 \mathrm{~cm} \times 2 \mathrm{~cm} \times 0,5 \mathrm{~cm}$. Bumbu terdiri dari gula merah $30 \%(b b)$, garam $4 \%(\mathrm{bb})$, laos $5 \%(\mathrm{bb})$, ketumbar $5 \%(b b)$, bawang merah $2 \%(b b)$, bawang putih $2 \%(b b)$ dan asam $4 \%$ (bb). Bumbu dibalurkan ikan Nila selama \pm 2 jam. Dendeng dipanaskan pada oven dengan suhu $60^{\circ} \mathrm{C}$ selama $20-30$ menit, dendeng yang sudah kering kemudian diangkat dan didinginkan.

Pembuatan bakso dan nugget ikan nila menggunakan prosedur sesuai (Effendi 2019). Bahan yang digunakan adalah ikan nila. Garam dapur yang digunakan sekitar 2,5\% dan bumbu penyedapnya sekitar $2 \%$ dari berat daging. Campuran bawang merah, bawang putih, perbandingan $15: 3: 1$. Filet daging ikan digiling halus. Selanjutnya tepung kanji, telur ayam dan bumbu halus dicampurkan ke dalam daging ikan yang sudah dihaluskan. Cetak adonan menjadi bulat kemudian dimasukkan ke dalam air mendidih dan dibiarkan hingga mengapung sendiri.

Pembuatan nugget ikan nila menggunakan bahan antar lain ikan nila, tepung terigu, tepung roti, butir telur, bawang putih, kaldu bubuk, garam, gula dan merica Prosedur pembuatan yaitu, pengocokan telur, penambahan bawang putih yang telah dihaluskan, kaldu bubuk, garam, gula, dan merica. Selanjutnya, penambahan tepung terigu dimasukkan ke dalam dan ditambahkan daging ikan yang telah dihaluskan. Adonan selanjutnya dikukus, setelah matang dan dingin dipotong-potong. Potongan dicelupkan dalam telur dan dibalur dengan tepung roti, dan digoreng (Effendi 2019).

Evaluasi penyuluhan dilakukan pada akhir kegiatan penyuluhan untuk mengetahui respons sasaran terhadap 
penyuluhan yang telah dilakukan, menggunakan alat berupa lembar kuesioner. Evaluasi dilakukan pada saat sebelum dan sesudah penyuluhan. Evaluasi dilakukan terhadap aspek sikap, pengetahuan dan tahapan adopsi inovasi.

Penentuan nilai aspek sikap sasaran:

Skala Likert $=\frac{\text { Total Nilai Skor }}{\text { Total Nilai Maksimum }} \times 100 \%$

Penentuan nilai perubahan dan peningkatan pengetahuan, keterampilan dan sikap sasaran:

Perubahan $=$ Nilai Akhir - Nilai Awal

$$
\text { Peningkatan }=\frac{\text { Nilai }_{1}-\text { Nilai }_{0}}{N_{\max }} \times 100 \%
$$

Keterangan:

Nilai 1 : Nilai Akhir

Nilaio: Nilai Awal

$\mathrm{N}_{\max }$ : Nilai tertinggi
Tahap adopsi inovasi, untuk menilai seberapa jauh perubahan tingkat adopsi sasaran setelah mendapat penyuluhan suatu program, diamati selama 9 minggu.

\section{HASIL DAN PEMBAHASAN \\ Hasil}

\section{Profil Kecamatan Darma}

Kecamatan Darma merupakan dataran perbukitan yang memiliki potensi perikanan yang dapat dikembangkan. Jenis tanah regosol kaya akan unsur hara dan baik untuk usaha pertanian maupun perikanan. Selain itu, terdapat tiga sumber air yaitu Waduk Darma, mata air Darma Loka, dan Sungai Cisanggarung. Waduk Darma telah dimanfaatkan sebagai media pembesaran ikan nila dan mas dalam KJA. Berikut adalah

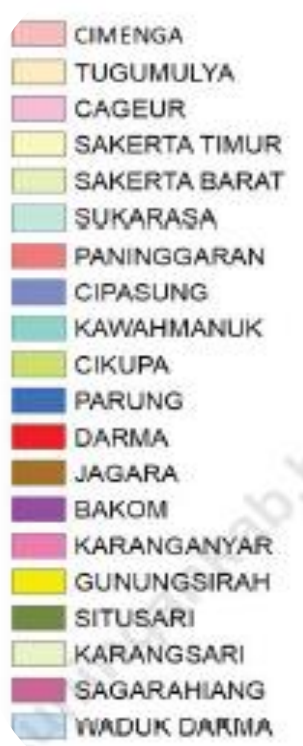

KECAMATAN DARMA

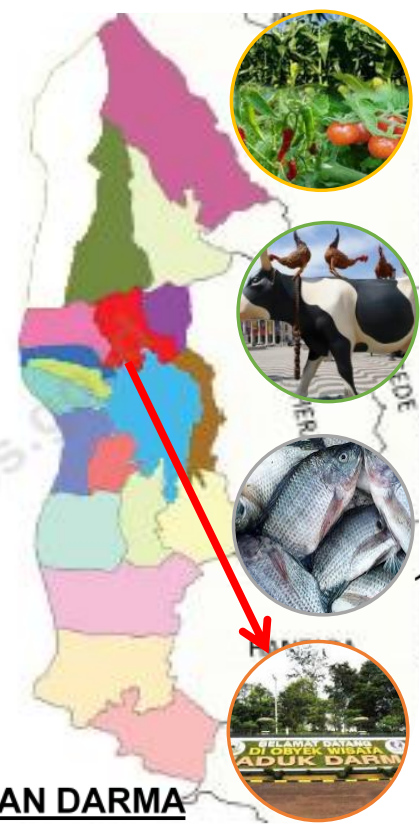

\section{Pertanian}

Padi 10.220 ton, Jagung 6.457 ton, dan Daun Bawang 6.312 dll.

\section{Peternakan}

Ayam 98.443 ekor, Ayam Petelur 26.836, Sapi 291 ekor, Domba 6.461 ekor, dll.

\section{Perikanan}

$3.459,1$ ton dengan jenis Ikan Mas 1.593,5 ton, Nila $1.605,4$ ton, Lele 87,7 ton, dll

\section{Objek Wisata}

Terdapat Waduk Darma dan Darma Loka sebagai sumber PDAM dan perikanan.

Gambar 1 Pemanfaatan potensi sumber daya alam di Kecamatan Darma 
Tabel 2. Perbandingan penerapan sanitasi higiene pada sasaran penyuluhan di Kecamatan Darma

\begin{tabular}{|c|c|c|c|}
\hline No. & Indikator & Sebelum Penyuluhan & Sesudah Penyuluhan \\
\hline 1. & Keamanan Air & $\begin{array}{l}\text { Air yang digunakan berasal dari PAM } \\
\text { yang dikelola oleh warga yang } \\
\text { bersumber dari mata air lokal. Air } \\
\text { langsung digunakan tanpa ada } \\
\text { perlakuan tambahan. }\end{array}$ & $\begin{array}{l}\text { Air yang digunakan berasal dari PAM } \\
\text { yang dikelola oleh warga yang } \\
\text { bersumber dari mata air lokal. Air } \\
\text { langsung digunakan tanpa ada } \\
\text { perlakuan tambahan. }\end{array}$ \\
\hline 2. & $\begin{array}{l}\text { Kondisi } \\
\text { kebersihan } \\
\text { permukaan }\end{array}$ & $\begin{array}{l}\text { Pelaku belum memperhatikan } \\
\text { kebersihan permukaan peralatan yang } \\
\text { akan digunakan secara intensif. Barang- } \\
\text { barang, peralatan, dan produk } \\
\text { ditempatkan dan diolah di atas } \\
\text { permukaan berbahan marmer dan } \\
\text { tripleks. }\end{array}$ & $\begin{array}{l}\text { Adanya perubahan tindakan yaitu } \\
\text { pelaku terlebih dahulu mencuci } \\
\text { peralatan setiap akan digunakan. }\end{array}$ \\
\hline 3. & $\begin{array}{l}\text { Pencegahan } \\
\text { kontaminasi } \\
\text { silang }\end{array}$ & $\begin{array}{l}\text { Upaya pencegahan terhadap } \\
\text { kontaminasi silang yang berasal dari } \\
\text { peralatan maupun bahan yang } \\
\text { digunakan masih sangat sederhana. } \\
\text { Pekerja hanya melakukan pembersihan } \\
\text { sebelum dan sesudah produksi saja. } \\
\text { Bahkan terdapat pekerja yang } \\
\text { melakukan proses sortir dan } \\
\text { pengemasan produk bersamaan dalam } \\
\text { wadah peletakan produk. }\end{array}$ & $\begin{array}{l}\text { Upaya pencegahan terhadap } \\
\text { kontaminasi silang yang berasal dari } \\
\text { peralatan maupun bahan yang } \\
\text { digunakan masih sangat sederhana. } \\
\text { Namun, terdapat perubahan dalam hal } \\
\text { penyimpanan bahan-bahan pembersih } \\
\text { yaitu mulai diletakkan di luar ruang } \\
\text { produksi. Bahkan terdapat pekerja yang } \\
\text { melakukan proses sortir dan } \\
\text { pengemasan produk bersamaan dalam } \\
\text { wadah peletakan produk. }\end{array}$ \\
\hline 4. & $\begin{array}{l}\text { Pengelolaan } \\
\text { Fasilitas } \\
\text { Kebersihan } \\
\text { pekerja }\end{array}$ & $\begin{array}{l}\text { Pengolahan masih menempatkan lokasi } \\
\text { produksi di dapur rumah tangga dan ada } \\
\text { pula dilakukan pada ada pula yang } \\
\text { dilakukan pada rumah produksi yang } \\
\text { terletak rapat di lingkungan pemukiman. } \\
\text { Rumah produksi tersebut hanya } 1 \\
\text { ruangan dan tanpa ada sekat pemisah. } \\
\text { Di mana belum terdapat fasilitas toilet, } \\
\text { ruang kantor, dll. }\end{array}$ & $\begin{array}{l}\text { Pengolahan masih menempatkan lokasi } \\
\text { produksi di dapur rumah tangga dan } \\
\text { ada pula dilakukan pada ada pula yang } \\
\text { dilakukan pada rumah produksi yang } \\
\text { terletak rapat di lingkungan pemukiman. } \\
\text { Rumah produksi tersebut hanya } 1 \\
\text { ruangan dan tanpa ada sekat pemisah. } \\
\text { Di mana belum terdapat fasilitas toilet, } \\
\text { ruang kantor, dll. }\end{array}$ \\
\hline 5. & $\begin{array}{l}\text { Pencegahan } \\
\text { adulterasi bahan } \\
\text { pangan dan non } \\
\text { pangan } \\
\text { (cemaran kimia, } \\
\text { fisik, dan } \\
\text { biologis) }\end{array}$ & $\begin{array}{l}\text { Produk dikemas rapi dalam kemasan } \\
\text { plastik. Belum adanya tempat } \\
\text { penyimpanan barang-barang non } \\
\text { pangan cemaran kimia, fisika, dan } \\
\text { biologis yang terpisah. }\end{array}$ & $\begin{array}{l}\text { Produk dikemas rapi dalam kemasan } \\
\text { plastik. Belum adanya tempat } \\
\text { penyimpanan barang-barang non } \\
\text { pangan cemaran kimia, fisika, dan } \\
\text { biologis yang terpisah. }\end{array}$ \\
\hline 6. & $\begin{array}{l}\text { Penggunaan } \\
\text { label dan } \\
\text { penyimpanan }\end{array}$ & $\begin{array}{l}\text { Label kemasan berupa cap sablon pada } \\
\text { luar permukaan kemasan. Belum ada } \\
\text { tempat/ruang penyimpanan khusus } \\
\text { untuk produk yang siap dipasarkan. } \\
\text { Seluruh bahan-bahan mentah yang } \\
\text { basah disimpan pada freezer. }\end{array}$ & $\begin{array}{l}\text { Label kemasan berupa cap sablon pada } \\
\text { luar permukaan kemasan. Belum ada } \\
\text { tempat/ruang penyimpanan khusus } \\
\text { untuk produk yang siap dipasarkan. } \\
\text { Seluruh bahan-bahan mentah yang } \\
\text { basah disimpan pada freezer. Namun } \\
\text { dibungkus pada satu wadah sesuai jenis } \\
\text { bahan. }\end{array}$ \\
\hline 7. & $\begin{array}{l}\text { Kesehatan } \\
\text { pekerja }\end{array}$ & $\begin{array}{l}\text { Kondisi kesehatan pekerja rata-rata } \\
\text { belum diperhatikan dan menjadi } \\
\text { tanggung jawab para pekerja itu sendiri. } \\
\text { Pekerja saat bekerja belum } \\
\text { menggunakan haircap, masker, atau } \\
\text { sarung tangan. Pekerja dapat keluar } \\
\text { masuk ruang produksi tanpa } \\
\text { memperhatikan kebersihan diri seperti } \\
\text { tangan dan kaki pekerja. }\end{array}$ & $\begin{array}{l}\text { Kondisi kesehatan pekerja rata-rata } \\
\text { belum diperhatikan dan menjadi } \\
\text { tanggung jawab para pekerja itu sendiri. } \\
\text { Pekerja saat bekerja belum } \\
\text { menggunakan haircap, masker, atau } \\
\text { sarung tangan. Pekerja sudah mulai } \\
\text { mencuci tangan setiap sebelum dan } \\
\text { sesudah produksi secara rutin. }\end{array}$ \\
\hline 8. & $\begin{array}{l}\text { Pencegahan } \\
\text { hama dan } \\
\text { penyakit }\end{array}$ & $\begin{array}{l}\text { Bangunan dan lokasi usaha yang } \\
\text { sangat sederhana dan berada di } \\
\text { tengah-tengah pemukiman belum } \\
\text { dilengkapi dengan biosecurity sehingga } \\
\text { pencegahan terhadap hama dan } \\
\text { penyakit masih kurang optimal. }\end{array}$ & $\begin{array}{l}\text { Bangunan dan lokasi usaha yang } \\
\text { sangat sederhana dan berada di } \\
\text { tengah-tengah pemukiman belum } \\
\text { dilengkapi dengan biosecurity sehingga } \\
\text { pencegahan terhadap hama dan } \\
\text { penyakit masih kurang optimal. }\end{array}$ \\
\hline
\end{tabular}


Gambar 1 berupa pemanfaatan potensi sumber daya alam di Kecamatan Darma.

Pelaku usaha perikanan sebanyak 910 jiwa, terdiri dari pengolah, nelayan, dan pembudidaya ikan. Para pelaku usaha tersebut ada yang tergabung dalam kelompok dan ada yang berusaha mandiri. Tercatat sebanyak 43 kelompok perikanan di Kec. Darma yang terdiri dari 26 Pokdakan, 10 KUB, 6 Poklahsar, dan 1 Pokmaswas. Data-data profil kelompok perikanan, potensi sumber daya alam bermanfaat untuk menentukan jenis dan materi penyuluhan (Yuniarti et al. 2020).
Kelompok Pengolah dan Pemasar (Poklahsar) belum menerapkan sanitasi dan higiene dalam memproduksi olahan ikan. Olahan ikan juga masih terbatas pada olahan ikan Darma adalah seperti nugget ikan, payam (paha ayam) ikan, otak-otak, batagor kering, nila krispi, dan lainnya. Pengolah belum memanfaatkan bahan baku ikan dari Waduk Darma, dengan alasan rasa ikan dihasilkan dari Waduk Darma lebih terasa amis dan berbau pelet ikan sehingga kurang diminati oleh masyarakat sekitar. Bahan baku ikan selama ini berasal dari laut
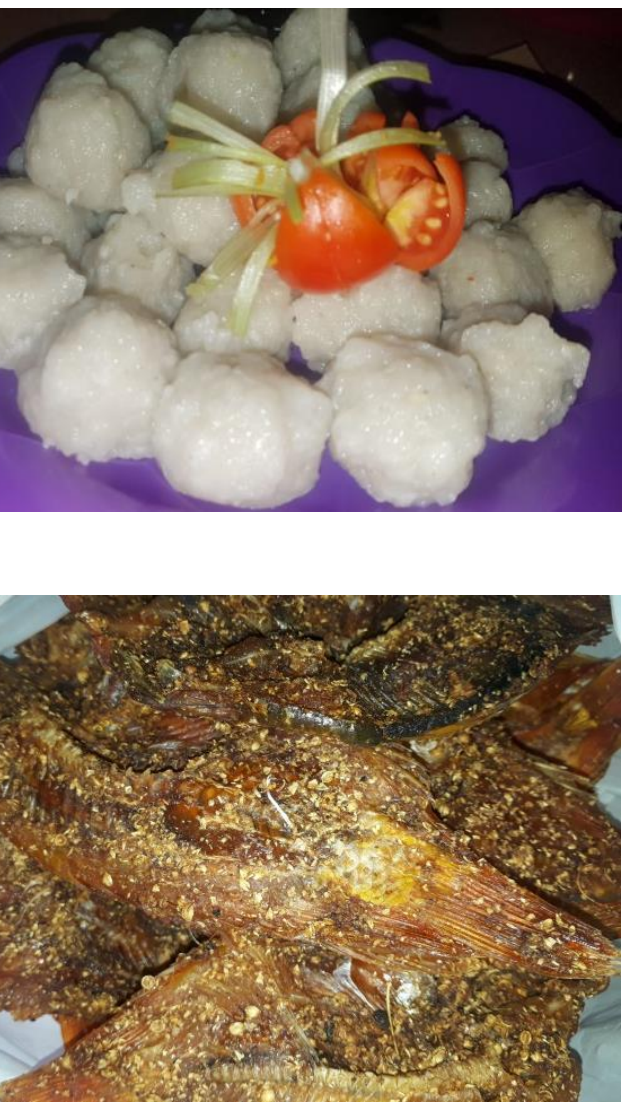

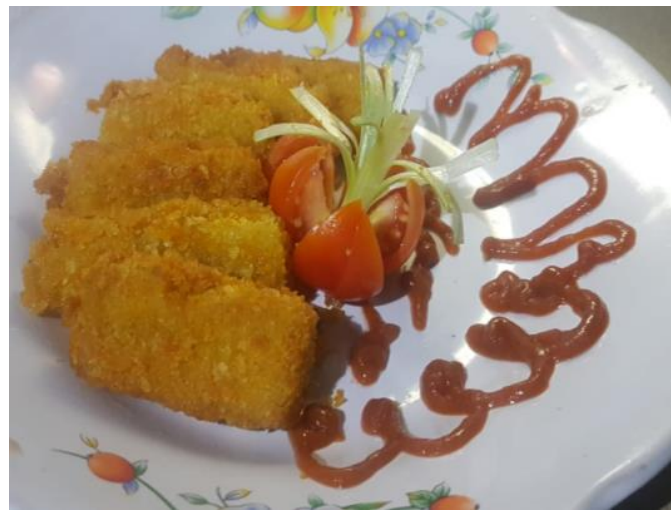

(b)

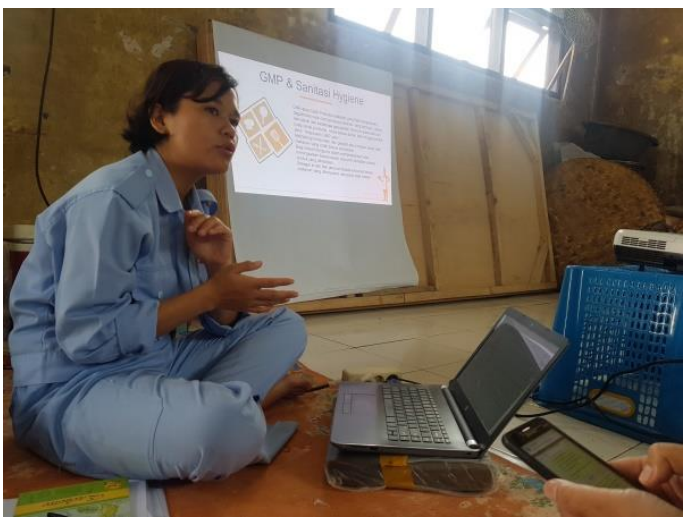

(d)

Gambar 2. (a) Produk bakso ikan nila; (b) Produk nugget ikan nila;

(c) Produk dendeng ikan red devil; (d) Penyampaian materi penyuluhan; 


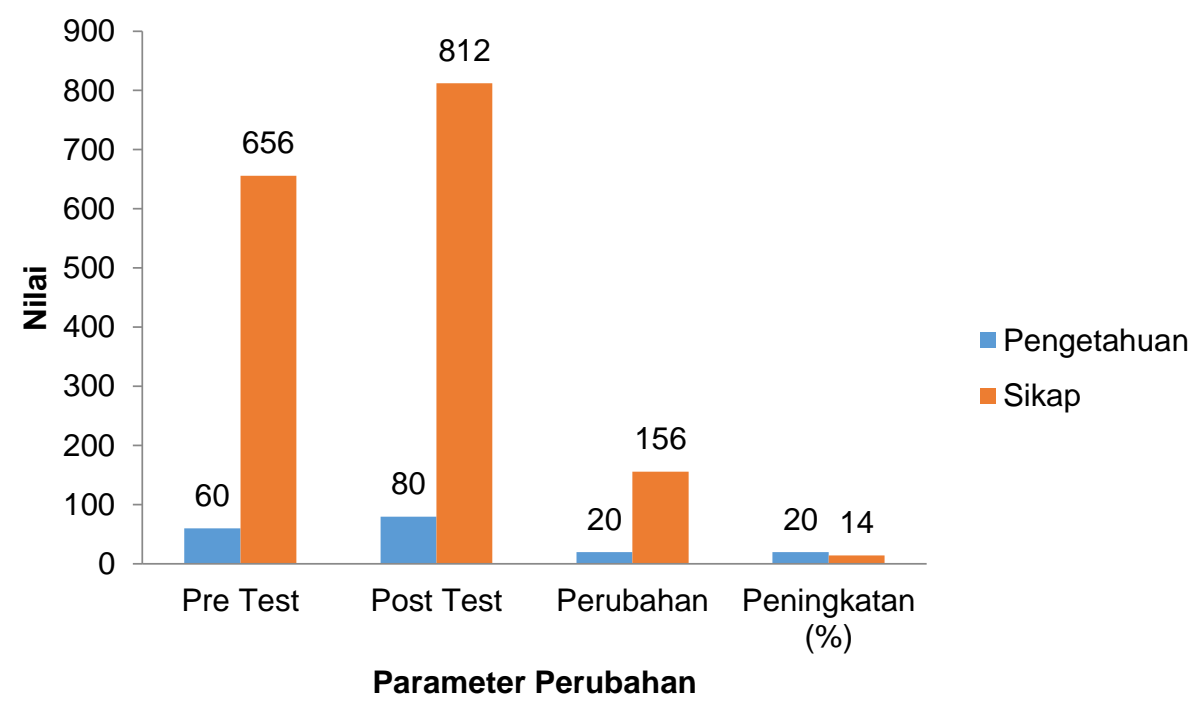

Gambar 3. Hasil evaluasi penyuluhan prinsip sanitasi higiene dan diversifikasi olahan

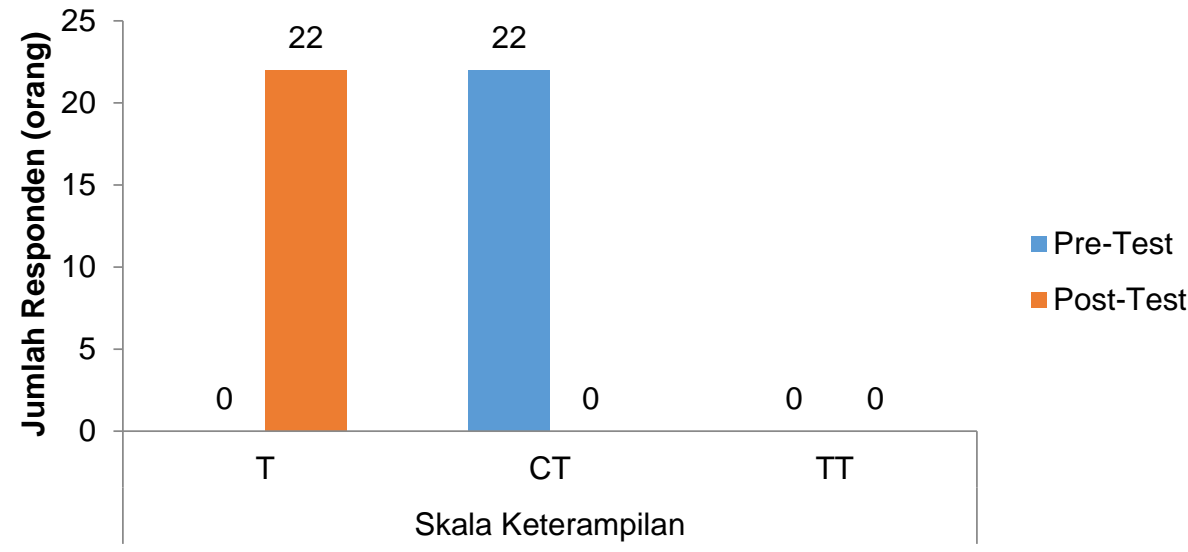

Gambar 4. Hasil evaluasi aspek keterampilan prinsip sanitasi higiene dan diversifikasi olahan

seperti ikan tenggiri, kuniran dan lainlain.

\section{Hasil Penyuluhan Penerapan Sanitasi} higiene

Prinsip sanitasi higiene yang diajarkan kepada sasaran belum dapat diterapkan secara maksimal, hal ini dapat dilihat pada Tabel 2, di mana perbandingan penerapan prinsip sanitasi higiene tidak terdapat perubahan yang jauh baik sebelum maupun sesudah penyuluhan.

Penyuluhan Diversifikasi Produk Olahan Hasil Perikanan

Sasaran penyuluhan terdiri dari Poklahsar Sagara Rasa dan Jagarasa 


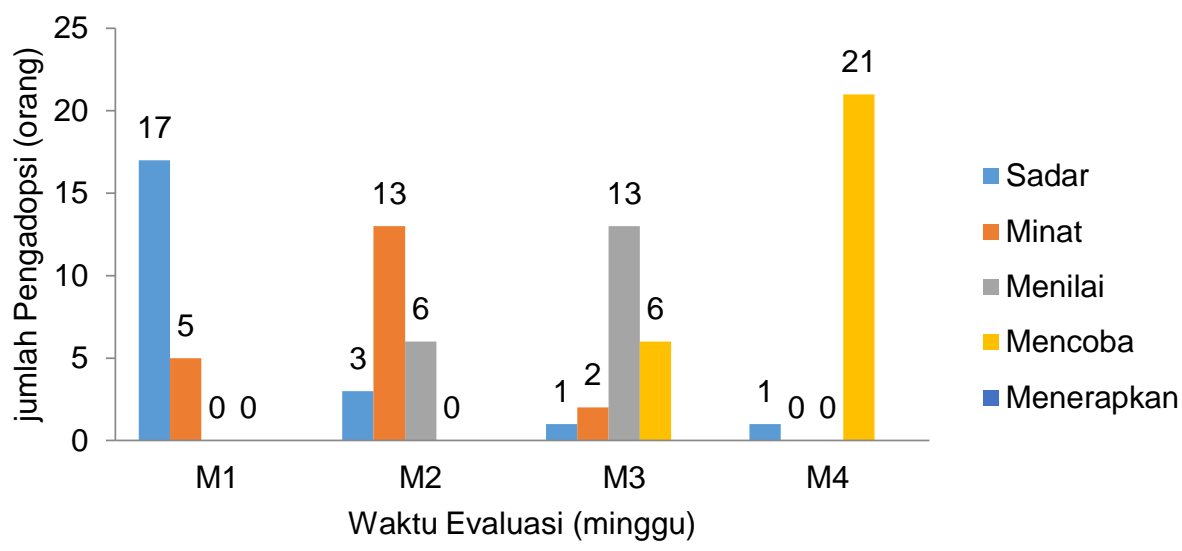

Gambar 5. Hasil adopsi inovasi penyuluhan prinsip sanitasi higiene diversifikasi olahan ikan

yang bertempat di Desa Jagara serta

Pokdakan Mina Sawargi di Desa Paninggaran. Pemilihan jenis olahan untuk penyuluhan diversifikasi olahan produk perikanan atas dasar permintaan langsung dari sasaran. Sasaran tersebut diajarkan cara pembuatan dendeng ikan, nugget, dan bakso ikan menggunakan bahan baku dari Waduk Darma. Ikan yang digunakan antara lain ikan mujair/nila dan ikan red devil. Harga ikan tersebut jauh lebih rendah dibandingkan ikan kunir yang biasanya digunakan pelaku pengolahan sebagai bahan baku. Harga ikan kuniran per $\mathrm{kg}$ adalah Rp.25.000. Harga ikan mujair per kg adalah Rp17.000. Sementara ikan red devil, pada dasarnya merupakan ikan hama pada KJA dan memiliki harga jual maksimal Rp. 5.000 per kg. Produk hasil olahan para sasaran disajikan pada Gambar 2.

\section{Evaluasi Penyuluhan}

Terjadi peningkatan pada aspek pengetahuan mengenai aneka macam olahan ikan. Aspek sikap terhadap diversifikasi olahan ikan. Pada saat sebelum penyuluhan, sasaran cukup setuju terhadap diversifikasi olahan ikan, kemudian menjadi sangat setuju terhadap diversifikasi olahan ikan. Pada aspek keterampilan dari 22 orang sasaran semula berada pada kategori cukup terampil terhadap diversifikasi olahan, menjadi terampil contohnya dalam hal mengolah aneka macam olahan ikan. Data peningkatan dapat dilihat pada Gambar 3 dan 4.

Adopsi inovasi dipengaruhi oleh sifat-sifat inovasi, kualitas fasilitator, dan status sosial-ekonomi penerima manfaat Mardikanto (2010). Sasaran masuk dalam kategori kelompok laggard yaitu kelompok orang yang tidak mau berubah (Rogers dalam Mardikanto 2010). Hasil aspek evaluasi sikap menunjukkan sa- 
saran menyatakan setuju namun pada kenyataannya belum ada sasaran yang mau untuk menerapkan prinsip sanitasi higiene. Ketua kelompok pengolahan tersebut sebelumnya telah mendapat pelatihan sanitasi, namun belum ada satu orang pekerja saja yang dengan sadar untuk menerapkan sanitasi diri. Hasil adopsi inovasi sasaran terhadap penyuluhan prinsip sanitasi dan higiene dan diversifikasi olahan ikan dapat dilihat pada Gambar 5.

\section{Pembahasan}

Kondisi kelompok pengolah dan pemasar perikanan (Poklahsar) seperti pada umumnya masih belum menerapkan cara produksi pangan olahan ikan yang baik. Bagian yang sering menjadi perhatian adalah belum diterapkannya prinsip sanitasi dan higiene pada pengolah ikan. Penerapan sanitasi dan higiene pada produksi olahan ikan ini penting dilakukan karena menentukan kualitas dan keamanan produk olahan yang dihasilkan (Wahyunanto dan Topowijono 2018). Penerapan sanitasi higiene meliputi sanitasi dan higiene bahan baku, sanitasi dan higiene bahan tambahan, sanitasi dan higiene air, sanitasi dan higiene pekerja, sanitasi dan higiene ruang pengolahan dan lingkungan serta sanitasi dan higiene produk akhir (Domili 2017).
Rendahnya pengetahuan pelaku pengolahan mengenai prinsip sanitasi higiene menyebabkan belum ada pelaku yang mau dan mampu menerapkan prinsip sanitasi higiene. Perilaku seperti penggunaan sarung tangan, haircap, celemek, hingga pembagian ruangan untuk berbagai aktivitas produksi dan penyimpanan barang, belum dapat diterapkan. UKM tradisional pada umumnya belum menerapkan sanitasi higiene pada peralatan produksi, proses produksi, kebersihan lingkungan produksi, hingga kebersihan karyawan (Ainezzahira et al. 2019). Kesadaran para pelaku usaha perikanan perlu ditingkatkan sehingga mereka lebih peduli dalam menjaga kualitas higiene sanitasi proses industrinya. Upaya yang dapat dilakukan antara lain pelatihan secara terus menerus terhadap para pelaku usaha (Elvyra, Roslim, dan Nazaruddin 2018).

Menurut Kamus Besar Bahasa Indonesia, diversifikasi adalah penganekaragaman usaha untuk menghindari ketergantungan pada ketunggalan kegiatan, produk, jasa, atau investasi. Diversifikasi olahan perikanan merupakan upaya untuk meningkatkan daya serap pasar dan pemanfaatan bahan baku ikan. Terdapat banyak macam olahan ikan seperti nugget ikan, dendeng ikan, baby fish nila, kerupuk, bakso, dan lainnya. Bahan baku ikan dari Waduk Darma mempunyai kelemahan yaitu bau 
yang kurang disukai. Teknik budidaya ikan dapat memengaruhi mutu organoleptik ikan segar yang dihasilkan (Yuniarti, Eliyani, dan Yudistira 2014). Kualitas bahan baku ikan mentah akan memengaruhi produk yang dihasilkan (Wulandari, Abida, dan Farid 2009). Pada hal-hal tertentu maka teknologi pengolahan yang tepat dapat memperbaiki tingkat penerimaan konsumen terhadap produk olahan ikan (Darmansyah, Utami, dan Muslih 2016), seperti penambahan bumbu, garam dan perendaman dalam tawas (Suryaningrum, Syamdidi, dan Rizki 2013).

Menurut Mardikanto (2009) penyuluhan adalah suatu proses perubahan sosial, ekonomi dan politik untuk memberdayakan dan memperkuat kemampuan masyarakat melalui proses belajar bersama yang partisipatif, agar terjadi perubahan perilaku pada diri semua pemangku kepentingan (individu, kelompok, kelembagaan) yang terlibat dalam proses pembangunan, demi terwujudnya kehidupan yang berdaya, mandiri dan partisipatif yang semakin sejahtera dan berkelanjutan. Permasalahan yang dihadapi oleh pelaku usaha perikanan di Kecamatan Darma disebabkan oleh kurangnya pemahaman dan daya partisipatif masyarakat dalam memanfaatkan sumber daya perikanan yang dihasilkan dari Waduk Darma. Penyuluhan merupakan upaya untuk meningkat- kan partisipasi masyarakat dalam memberdayakan pelaku usaha (Bahua 2015). Hasil evaluasi penyuluhan menunjukkan bahwa terjadi peningkatan pengetahuan, sikap, dan keterampilan pengolah terhadap diversifikasi olahan ikan. Penyuluhan mampu mengubah keadaan sasaran menjadi lebih meningkat pengetahuan, sikap dan keterampilannya. Selanjutnya, untuk mencapai peningkatan kesejahteraan sasaran maka diperlukan pendampingan penyuluhan yang berkelanjutan sampai dengan terciptanya kemandirian sasaran atau bahkan sasaran mampu membagikan pula ilmunya kepada pelaku lainnya. Hal ini dikarenakan bahwa jumlah penyuluh yang melayani daerah Kecamatan Darma hanya satu orang yaitu Ibu Lina Marliana, S.Pi. Penyuluh tersebut juga bertugas pada 2 wilayah kecamatan lainnya. Penyuluh menjadi orang yang berperan penting dalam pemberdayaan masyarakat. Peran penyuluh berpengaruh signifikan terhadap penguatan kelompok dan kemandirian kelompok (Wardani dan Anwarudin 2018).

\section{SIMPULAN DAN SARAN}

Kecamatan Darma memiliki sumber daya alam dan manusia yang berpotensi untuk dikembangkan. Kelompok pengolah dan pemasar (Poklahsar) belum memanfaatkan ikan dari Waduk Darma untuk meningkatkan kesejahteraan- 
nya. Peranan penyuluhan mengenai sanitasi dan higiene pembuatan olahan ikan dan diversifikasi olahan ikan dapat meningkatkan pengetahuan, sikap dan keterampilan para pengolah. Walaupun dari hasil evaluasi adopsi inovasi, diperoleh hasil karakteristik sasaran yaitu cenderung termasuk dalam kategori Kelompok Penganut Dini (early majority). Pendampingan oleh penyuluh diharapkan dapat dilakukan secara terus menerus sehingga penyuluhan tidak berhenti setelah selesai, namun dapat dilanjutkan sehingga pemberdayaan pelaku usaha dapat terus berjalan dan menjadikan pelaku usaha lebih mandiri.

\section{PERSANTUNAN}

Penulis berterima kasih kepada Penyuluh Kecamatan Darma Ibu Lina Marliana, S.Pi, yang telah membantu menjembatani komunikasi dengan para pelaku usaha.

\section{DAFTAR PUSTAKA}

Ainezzahira, Khairunnisa, Hafiza Dwi Multri, Veronica, Baiq Mirna Fitriani, Turmaningsih Surya Pratama, Rezki Alhamdi, dan Warsono El Kiyat. 2019. "Evaluasi Sanitasi Pangan pada Industri Rumah Tangga Pengolahan Tahu di Kelurahan Bojong Nangka, Kabupaten Tangerang." VITKA JMP 1(1):1-5.
Bahua, Mohamad Ikbal. 2015. Penyuluhan dan Pemberdayaan Petani Indonesia. 1 ed. Gorontalo: Idea Publishing.

BPS Kabupaten Kuningan Jawa Barat. 2018. Kecamatan Darma dalam Angka.

Darmansyah, Eva Utami, dan Khoirul Muslih. $2016 . \quad$ "Analisis Penerimaan Konsumen terhadap Olahan Makanan Presto Tangkapan Sampingan Ikan Pepetek." Akuatik Jurnal Sumberdaya Perairan 10(2):3945.

Effendi, Irwan. 2019. "Pelatihan Pembuatam Bakso dan Nuget Ikan bagi Ibu Rumah Tangga Kampung Minas Barat Kabupaten Siak." Journal of Rural and Urban Enpowerment 1(1):61-66.

Elvyra, Roza, Dewi Indriyani Roslim, dan Nazaruddin Nazaruddin. 2018. "Pelatihan Standar Higiene Dan Sanitasi Untuk Peningkatan Pemberdayaan UKM Olahan Ikan Patin." Jurnal Pengabdian UntukMu NegeRI 2(2):49-54. doi: 10.37859/jpumri.v2i2.837. 
Harnisah, Harnisah, Slamet Riyadi, dan Fitra Mulia Jaya. 2018. "Karateristik Dendeng Ikan Nila (Oreochromis niloticus) dengan Konsentrasi Penambahan Gula Aren Berbeda." Jurnal IImu-ilmu Perikanan dan Budidaya Perairan 13(2):83-87. doi: 10.31851/jipbp.v13i2.2854.

Mardikanto, Totok. 2009. Sistem Penyuluhan Pertanian. Surakarta (ID): UNS Press.

Mardikanto, Totok. 2010. Komunikasi pembangunan: acuan bagi akademisi, praktisi, dan peminat komunikasi pembangunan.

Surakarta (ID): Sebelas Maret University Press.

Putri, Jasmine Addinda, Tatty Yuniarti, dan Ita Junita Puspa Dewi. 2019. "Analisa Permasalahan

Penyuluhan Perikanan di Kecamatan Cigasong Kabupaten Majalengka." Jurnal Penyuluhan Perikanan dan Kelautan 13(2):149-68. doi: 10.33378/jppik.v13i2.115.

Sigalingging, Ria Irama Kristiani. 2019. Laporan Praktik Keahlian Potensi Wilayah Perikanan untuk Pengembangan Usahan Perikanan di Kecamatan Darma Kabupaten Kuningan Provinsi Jawa Barat. Bogor (ID).
Suryaningrum, Theresia Dwi, Syamdidi Syamdidi, dan Erna Maya Rizki. 2013. "Penggunaan Berbagai Garam dan Bumbu Pada Pengolahan Pindang Ikan Lele Dumbo (Clarias gariepinus)." Jurnal Pascapanen dan Bioteknologi Kelautan dan Perikanan 8(1):23. doi: 10.15578/jpbkp.v8i1.50.

Wahyunanto, Saefualloh, dan Topowijono. 2018. "Penerapan Hygiene dan Sanitasi Dalam Upaya Peningkatan Mutu Kualitas Food and Baverage (Studi Pada Pantai Konang Desa Ngelebeng Kecamatan Panggul Kabupaten Trenggalek)." Jurnal Administrasi Bisnis 58(2):146-54.

Wardani, dan Oeng Anwarudin. 2018. "Peran Penyuluh Terhadap Penguatan Kelompok Tani dan Regenerasi Petani di Kabupaten Bogor Jawa Barat." Journal Tabaro 2(1):191-200.

Wulandari, Dyah Agustin, Indah Wahyuni Abida, dan Akhmad Farid. 2009. "Kualitas Mutu Bahan Mentah dan Produk Akhir pada Unit Pengalengan Ikan Sardine di PT. Karya Manunggal Prima Sukses Muncar Banyuwangi." Jurnal Kelautan 2(1):40-49. doi: 10.21107/jk.v2i1.901. 
Yuniarti, Tatty, Jasmine Adinda Putri, Ita Junita Puspa Dewi, dan Ani Leilani. 2020. "Adoption of Fisheries Diversification Innovation in Poklahsar in Cigasong SubDistrict, Majalengka District." Jurnal Penyuluhan 16(2):289-302. doi: 10.25015/16202030683.
Yuniarti, Tatty, Yuke Eliyani, dan Alvi Nur Yudistira. 2014. "Karakteristik Organoleptik Filet Ikan Patin (Pangasionodon hypophthalmus) dari Tiga Lokasi Budidaya di Kabupaten Bogor." Jurnal Penyuluhan Perikanan dan Kelautan 8(1):40-46. doi: 10.33378/jppik.v8i1.46. 